\title{
"Formative Exchanges" in Late Antique Eurasia (1): Zoroastrianism, Manichaeism, Judaism, and Christianity
}

\author{
EDUARD IRICINSCHI \\ CNRS, Paris and The Sapienza University of Rome
}

\begin{abstract}
The article first presents the theoretical, historical, and methodological presuppositions that guided the organization of the first "Formative Exchanges in Late Antique Eurasia" workshop at the Käte Hamburger Kolleg (KHK), Ruhr-Universität Bochum, in 2017. In the second part, the article summarizes the papers presented at this meeting and identifies the emerging questions and results shared by the participants.

KEYWORDS formative religion, religious encounters, Zoroastrianism, Manichaeism, Christianity, Judaism, Persian Empire, Roman Empire
\end{abstract}

\section{Introduction}

The notion of "formative religion" found both its initial methodological inspiration and its ulterior developments in the academic research carried out at the Käte Hamburger Kolleg (KHK), Ruhr-Universität Bochum, on religious contacts in Eurasia, between 2014 and 2019, after the guest editors of this issue, Eduard Iricinschi and Kianoosh Rezania, joined the project on "Dynamics in the History of Religions between Asia and Europe," directed by Volkhard Krech (2008-2018), and by Alexandra Cuffel and Kianoosh Rezania (2018-2020). ${ }^{1}$

The KHK methodology of identifying religious contacts and analyzing the conditions under which these occurred and left meaningful changes in their wake enabled the editors and their guests to explore the notion of "formative religion" at multiple levels. First, investigating the formative stages of any given religion emancipates scholars from engaging the issue of religious origins, always an enterprise fraught with theological baggage by virtue of

$1 \quad$ For more details on the theoretical background of the research carried out at the Käte Hamburger Kolleg, RUB, see Krech (2012a, 2012b). 
its own definition. Second, by enlarging the scope of the analysis beyond singular religious formation-also a matter of theological mythmaking - to the matter of encounters between various religious formations, the historians of religion engaged in this KHK enterprise turned their attention to the notion of "formative exchanges."

The above double methodological assumption opens the way to envisage "religions" in an unremitting fluctuation and exchange with their neighbors' rituals and narratives. Just as no man stays "an island" for too long, the decade-long explorations in religious contacts, carried out at the Käte Hamburger Kolleg in Bochum, showed that no "religion" remained "pure," that is, uncontaminated, unrelated to others, or unexposed to cultural influences coming from what it considers to be, normatively, outside geographical, political, and ideological realms. Third, and finally, if one considers "formative religion" to be taken both as a considerable step away from the enchantment with religious origins and as a measure of variable hybridity, one could also understand the establishment of an organized religion as a processual development unraveled through dialogue, mimesis, resistance, and rejection.

The KHK analytical concepts of "typology," "purity," "media," "gender," "dynamics and stability," "transcendence and immanence," "secrecy," and "tradition," elaborated and tested throughout the years of research, provide scholars with the necessary critical tools to evaluate the ways in which "formative religions" developed as the outcome of interactions between various religious formations, either of the same orientation, also labelled as "intra-religious boundaries," or with different aspects, identified at the Käte Hamburger Kolleg as "interreligious dynamics." 2 The most appropriate way to identify religious alterations which took place following social and literary interactions would be to identify the resulting "formative exchanges" and document them in their processual development. This also means that one needs to track changes recorded on both camps of religious encounters in an ongoing process of reciprocal information exchange between the sides in contact.

At the pragmatic level, between 2017 and 2019, Iricinschi and Rezania envisaged the exploration of this ever-changing landscape of mutual influences at work in religious encounters in three stages. In 2017, they organized a workshop on "Formative Religious Exchanges between the Sasanian Empire and Late Antique Rome" dedicated to the exploration of issues of religious interactions between Zoroastrians, Manichaeans, and Christians in both the Persian Empire and in the Eastern Mediterranean. The initial working hypothesis suggested that formative dynamics of contacts, interactions, and exchanges took place between Zoroastrianism, Manichaeism, and Christianity at multiple levels: religious, ritual, material, and experiential. As a result, Iricinschi and Rezania suggested exploring the rhetoric, ritual, and material scope of religions represented as "minorities" within larger ethnic and ideological landscapes, such as Christians and Manichaeans in the Sasanian Empire, or Manichaeans and Jews in the Roman Empire. At the same time, they sought to investigate how the subsequent reactions from the political, ethnic, and religious "majority" of the Persian and Roman Empires led not only to various manners of accommodation or rejection of religious minorities by the religious establishment, but also to the transformation of the above-said majorities because of religious contacts. To discuss these formative interactions, they invited scholars to investigate late antique primary sources in Middle Persian, Parthian, Syriac, Armenian, Georgian, Coptic, Greek, and Latin, which describe religious contacts in the late antique Sasanian and Roman Empires.

Encouraged by the success of the 2017 workshop, whose measure is hopefully reflected in

2 For details, see the KHK Working Paper Series available online: https://er.ceres.rub.de/index.php/ER/con cepts (accessed December 4, 2020). 
the papers included in this Special Issue of Entangled Religions, the two scholars associated with this project attempted to replicate it a year later. In 2018, they shifted their geographical focus eastwards and focused on the eastern Iranian plateau, the Indian subcontinent, and Central Asia. The temporal interval of the investigation, however, remained unchanged, namely, the first millennium CE. The organizers preserved the binomial conjunctures between Zoroastrianism and Manichaeism but chose to explore its relevance against the Central Asian background shaped by religious interactions between Zoroastrianism, Manichaeism, and Buddhism. As a result, they investigated formative dynamics of contacts, interactions, and exchanges that took place between these religions at the same multiple levels: knowledge, ritual, material, and experiential. While they still considered the literary and social negotiations Manichaeism and, to a limited degree, Christianity conducted with Zoroastrianism, as an imperially-mandated religion, in the Sasanian Empire between the third and the seventh centuries, the second-year workshop added the perspective of religious interactions across Central Asia and into China to the end of the first millennium $\mathrm{CE}$ as the new inquiry focus.

This approach opened the avenue of surveying the meetings between Western Asian religions (Zoroastrianism and Manichaeism) with East Asian religions (Buddhism and Jainism) by identifying some of the major building blocks of religious encounters. An open list of these common platforms of religious interactions includes the following: geography and landscape as key features in shaping religious encounters; negotiating expressions of materiality in religious settings; shared associations between mythological vocabularies and social or ritual practices across various religions; shared ritual skills and ritual specialists; religious expressions of survival and accommodation techniques, such as commercial exchanges, medical care, and ritual meals; cosmologies as texts informing ethics, rituals, and politics; and sites of literary interactions, interpretive strategies, and narrative exchanges. In analyzing the ways in which religions were imported, adopted, and transformed in Western and Central Asia, the 2018 workshop regarded transformation, hybridization, and adaptation as various outcomes of religious encounters. To discuss these formative interactions of religions on the move, the organizers invited scholars to investigate primary sources in Middle Persian, Parthian, Greek, Latin, Coptic, Syriac, Sogdian, Uighur, and Chinese, which describe religious contacts across Western and Central Asia until the end of the first millennium CE.

Most recently, in 2019, the research team preserved the binomial formative encounter between Zoroastrianism and Manichaeism of the first two workshops as well as its development across the above-presented "platforms of religious interaction," the geographical focus of the second workshop, but shifted the period focus to the first centuries of the Islamic period. As a result, in 2019, the team investigated the relevance of the religious interactions in the Islamicate world, on the Iranian plateau, the Indian subcontinent, and Western and Central Asia in the first seven centuries of the Islamic period. The 2019 "Formative Exchanges" workshop surveyed aspects of the interaction between the three religions of Zoroastrianism, Manichaeism, and Islam, and at the same time analyzed religious discourses and practices shared by Zoroastrianism and Manichaeism in the Islamicate world several centuries after Mani's own lifetime. For the sake of precision, the organizers of the workshop followed John C. Reeves's use of Marshall G.S. Hodgson's definition of "Islamicate" as designating matters which refer "not directly to the religion, Islam, itself, but to the social and cultural complex historically associated with Islam and the Muslims, both among Muslims themselves and even when found among non-Muslims" (Reeves 2011, 7; Hodgson 1974, 1:59). The 2019 "Formative Exchanges" meeting also explored the ways in which Islamicate literacy provided the 
means of adapting, translating, and adopting Zoroastrian and Manichaean texts. At the same time, the organizers extended their investigation to the literary contexts in which these texts were produced (the literature of religious disputations) and to their Sitz im Leben (polemical encounters). In analyzing the ways in which religious identities were shaped by the above description of series of literary codifications and re-descriptions, the scholars invited to the workshop treated transformation, hybridization, adaptation, reformation, and reorganization as various outcomes of religious encounters.

During the three years of investigating historical and geographical variations of the concept of "formative religion," Iricinschi and Rezania adopted the following working definition of it. As a preliminary exercise in defining fuzzy conceptual units, they regarded "formative religion" as the sum of social, political, religious, and literate processes through which the members of a given religious community-once they found themselves in a situation of possible religious interaction-adopt, borrow, copy, denigrate, and even integrate what they perceive to be the practices and tenets of other vicinal religious formations. As a result, their own religious practices and narratives will possibly be altered and, as an indirect effect, carry the potential to transform the very practices and ideologies they appropriated in the initial mimetic approach.

For this process of the crystallization of the concept of "formative religion" to take place, one needs to identify, also with a provisory title, few required conditions. The constellation of religious exchange leading to co-formative exchanges occurs a) in a situation of "religious contact"; b) in a social, economic, and political context in which various religious formations inherited and further experimented with forms of negotiating coexistence (such as the Sasanian Empire and the Roman Empire in late Antiquity, in the case of this special issue of Entangled Religions), and, finally, c) a collection of shared practices, vocabularies, objects, and ideas. Following the theoretical work of Ann Taves (2009, 161-68), one could regard these shared platforms as building blocks of religious encounters. As mentioned above, these common platforms of religious interactions could include: highlighting geography and landscape as key features in shaping religious encounters; negotiating expressions of materiality in religious settings; underlying shared associations between mythological vocabularies and social or ritual practices across various religions; shared ritual skills and ritual specialists; religious expressions of survival and accommodation techniques, such as commercial exchanges, medical care, and ritual meals; and cosmologies as texts informing ethics, rituals, and politics.

To take just one example, from Manichaeism, a shared platform could include practices of hybridization, carried in Manichaeism on multiple levels, such as social, religious, ontological. Situations of religious contact presuppose encoding and decoding hybridity, expressed through new, unusual divinities, or through exchanges at the level of materiality, art, and literacy. Mani dedicated most of his cosmological narrative and almost his entire mythological lore to depicting a religious ontology of the mixed elements between darkness and light, angels and demons, vices, lust, and abstinence. His description of the realm of Darkness and of its archons or demons promotes an ontology of mixing to describe the world of Darkness and its inhabitants. This points us to the performative dimensions of religion, which aim at consolidating the established social formations through performative associations of remembering persecution, at placing it within an emotional landscape, and at reenacting it in a ritual context with theatrical dimensions, in emotionally enhanced displayed performance. Theatricality in religious ritual and its association with increased levels of emotions represents a 
constant feature across ancient and late antique religions throughout the Persian world and the Greco-Roman cultures.

\section{The Contributions of Formative Exchanges I}

In his keynote paper, "Mazdeans and Christians Facing the End of the World: Circulations and Exchanges of Concepts," Antonio Panaino (2020) offers an evaluation of the parallel developments and mutual exchanges between Mazdeans and early Christians: while the latter's millennialism shows Iranian influences, the Zoroastrian doctrine of universal mercy displays parallels with the Origenian notion of apokatastasis. Panaino sets the stage for the evaluation of a late antique cultural continuum across languages, in which the conceptions of "time," "salvation," and "evil" received ontological substance and mythological expressions, only to travel between cultural urban centers and seats of power between Western Asia and the eastern Mediterranean. He evaluates the theological and logical consequences of the "divine prerogatives of time," understood on the Iranian highlands as a meditation between the infinite qualities of time and its worldly instantiations, in the formation of "planetary millenarianism with its pattern of the seven millennia" (2-3). Panaino also establishes the deep ties of an "expansion and dilation of time" with the Young Avesta and finds a most telling illustration of it in the Mazdean liturgical overlapping performance of a "concatenation of rituals (...) from one priestly college to another, and in an uninterrupted sequence to cover (and protect) the whole time of the world" (4).

Much to historians' delight and Christian theologians' fright, a dual conception of time, articulated by a mitigated dualistic mythological landscape, lends temporary ontological substance to evil, and consequently, it inevitably leads to what Panaino calls "a kind of apokatastasis," namely, "the total elimination of hell and of the complete remission of sins to all persons previously condemned to the harshest punishment" (5). To demonstrate the revolutionary political and religious principle of "divine mercy for the whole of humanity with the total elimination of hell," Panaino investigates the available specks of evidence and assembles a dossier of primary sources (Škand Gumānig Wizār IV, 100-101; Anthologies by Zādspram XXXV, 47; Dādestān ì Dēnig, [Book of the] Religious Judgements XXXVI, 106; Bundahišn III, 26-27). The author illuminates the theme of the workshop impressively by connecting this to the Origenian doctrine of complete restoration of all beings after the final judgment (apokatastasis), whose echoes he detects not only in Syria (the School of Nisibis and Stephen bar Sudaili, supposed to the author of the Book of Hierotheos on the Hidden Mysteries of the House of God), but also in the affairs of Justinian politics as they were reflected by the sentences against Origen in 543/44 and 554 (the second Origenist controversy).

In her contribution "Teaching with Images among the Jews and Manichaeans of Late Antique Mesopotamia. A Comparison of Doctrinal Content, Didactic Function, and Oral Context," Zsuzsanna Gulácsi (2020) compares and connects the didactic functions of two pictorial forms of late antique religious art: that displayed in the Dura-Europos synagogue and that, to the east, of Manichaean expression. By doing this, she places the Dura synagogue and its Jewish practices within the Mesopotamian context, and she argues that Manichaean religious art enhances our understanding of the Dura-Europos Jewish synagogue. She uncovers parallels developments between the religious and artistical development of the two communities. Gulácsi argues that, beginning with the second half of the third century CE, both the Jews and the Manichaeans of Mesopotamia spread and augmented their religious messages using 
pictorial devices. She ranges side by side Mani's religious activity and promotion of his message after $240 \mathrm{CE}$ through visual representation in a pictorial scroll and the renovation of the Dura synagogue in 244/245 CE, expressed through the didactic paintings on its four walls, "encircling the community in three dense registers of figural art" (5). This leads her to uncover three layers of functional similarities between late antique Jewish and Manichaean forms of religious art, expressed in parallel "regional development of techniques of religious instruction": they both represent relevant episodes expressed in their respective religious literature; their images were used as teaching tools, and helped with the oral education of the community (7). Gulácsi's insight follows her previous important work, Mani's Pictures (Brill, 2015), and brings her methodology into new territories, in that it matches the "textual references written between the mid-third and late fifth centuries in primary Manichaean and secondary polemical accounts" to the paintings in the Dura synagogue.

The two sets of data Gulácsi sets side by side, extracted from written Manichaean sources and painted Jewish representations, do not align perfectly. "Beside a prayer (on three fragments of a parchment scroll) and the various inscriptions (on the ceiling tiles and murals of the synagogue), the Duran Jews and their visitors did not leave behind textual records," she writes (8). Yet it is precisely this informational incongruence that gives rises to a rich hermeneutic interplay of sharing religious practices of proselytism and education in late ancient Mesopotamia in Gulácsi's article. "Without arguing for direct influence between the two communities, I view their use of pictorial art as part of a shared phenomenon of techniques of religious instruction" (9). Sharing occurred at some time between 240 and 256, she argues, as Manichaean missionaries from the East were bound to enter Dura on their westward way. Moreover, Gulácsi points to Ctesiphon as the common source of artistic craft behind both religious cultures: "Model-books from the nearest metropolis, Ctesiphon, would explain the systematic use of Iranian visual language (garments, throne, investiture, and triumph motifs) throughout the panels of the synagogue" (footnote 7). And the Manichaean books were intimately associated with Mani's book of paintings, The Book of Pictures, in the process of proselytism and education. Mani, Gulácsi writes, "established the systematic exposition of his complex doctrine in a set of images stored in a book format" (17). Gulácsi treats the two different media of writing and painting in Manichaeism and Judaism in Mesopotamia as two "houses" for topics related to "prophetology, eschatology, and polemics" situated in an educational continuum of religious practices (22). In doing this, she underlines the practices of Manichaean religious literacy in their dual aspect, written and depicted, illustrating it with primary sources about early Manichaean proselytism. Furthermore, Gulácsi identifies a similar "duality of doctrinal communication" in the painted walls of the Dura synagogue. The topography and locus of this duality changes: if the Manichaean missionaries traveled across lands with Mani's written books and his Book of Paintings, the Jewish devotees had access, in the meeting hall of Dura synagogue, both to the Torah, "placed in the dedicated space of its aedicula," and to "painted/visual collection of the biblical narratives displayed panel by panel on all four walls in three registers" (31).

Both the Jewish murals and Mani's Book of Pictures dealt with, according to Gulácsi, three common themes, reflecting three main areas of communication: prophetology, eschatology, and polemics (against idol worship). Moreover, both the Manichaeans and the Jews of Mesopotamia adopted pictorial means for education. Using images to teach, worship, and proselytize, Gulácsi argues, increases the likelihood that the religious message travels fast across cultures and linguistic barriers: "Conveying doctrine by pictorial means is especially 
handy in multi-lingual missionary contexts possibly associated not only with the Manichaeans, but also with Jewish diaspora communities that increased converts to Judaism at this time" (42).

Gulácsi adds the didactic dimension to the two meant to describe the functions of the Dura synagogue, namely liturgical and artistic. To be more precise, "the narrative pictorial program of its meeting hall fulfilled a didactic function in a special sermon, separate from liturgy" (53). Gulácsi uses the pictorial details of the Dura synagogue as historical proof for religious didactic practices: "At Dura, the act of reading from a scroll is documented by being depicted" (54). This takes her reasoning one step further: "art could have played a leading rather than a subordinate role in a sermon" (59). Thus, according to this bold hypothesis, the close similarities between textual descriptions of the uses of Mani's Book of Paintings and the arrangement of the pictures in the Dura synagogue allows her to unseat textual preeminence in late antique Jewish educational practices and place "teaching with images" as a fundamental educational method, in which, Gulácsi argues that "art could have played a leading rather than a subordinate role in a sermon" (59). Mani's Book of Paintings and equally the paintings on the walls of the Dura synagogue commanded a different somatic relation to the communication of the religious message, and this entailed both a different expository order and a different educational scenario, one in which the speaker explains and unfolds an elaborated image to their audience. Says Gulácsi: "The narrative panels of the Dura synagogue played the leading role in planning and staging an image-based sermon by serving as the starting point of instruction" (59).

Jason D. BeDuhn's article provides a new viewpoint of the notion of "formative religion." In "The Co-formation of the Manichaean and Zoroastrian Religions in Third-Century Iran" (2020), BeDuhn proposes the thesis of a simultaneous development of Zoroastrianism and Manichaeism in the third century CE. Following the seminal works of Prods Oktor Skjærvø, BeDuhn locates the traces of this parallel process "against the background of older Iranian religious cultural traditions" (see the paper's abstract) and in divergent "systems of interpretation and application." Paying attention to a reconstructed late antique religious landscape, BeDuhn adds more newly edited primary texts to this point the view which grants Manichaeism originality in the composition of its mythology and Zoroastrianism a more reactive role. Quietly radical, BeDuhn's article proposes the replacement of the notion of "religion" for ancient Zoroastrianism and of the "official doctrine" of Zoroastrianism "at a time when nowhere else on earth was there such a thing as a 'religion' [...] at a time when priestly institutions authorized myths, ritual scripts, purity codes, and other elements of regional religious culture, held together at most by a loosely-defined theory of efficacy in relation to divine beings" (2). He criticizes the narrative, promoted by modern religious studies scholars, of Zoroastrianism and Manichaeism as religions that were "founded, lost, and reconstructed" (2). BeDuhn revisits the theme of his important 2015 article, to which Rezania's contribution relates, to associate the occurrence of religious pluralism in Western Asia with the rise of non-nativism forms of worshiping gods, or, to use BeDuhn's own definition of religion, "organized systems of beliefs and practice disembedded from particular societies and cultures" (4). Two religious formations competed to appropriate and re-shape the inherited Iranian variety of "cultural traditions," according to BeDuhn: Mani and Kerdīr, in competition and reciprocal emulation, contributed to the formation of Manichaeism and that which crystallized as Zoroastrianism. "Mani crafts a working definition of religion as the product of revelation, authorized by a founding authority, organized as a community, guided by textual resources" (9). 
Engaged in horizontal cultural exchange, borrowing, and permutations, Mani and Kerdīr, or later, "Manichaeism" and "Zoroastrianism," competed to appropriate the following characteristics of Iranian culture: 1) a "dualistic universe"; 2) "the myth of primordial combat," that is, the use of the preexisting Iranian pantheon and its adaptation to hierarchical theologies; 3) "veneration and ritual support of natural elements" (identification with natural elements and granting them redeeming roles); 4) the "use and interpretation of Iranian religious literature" such as "Gāthās, Yašts, and other Avestan literature"; 5) the adoption of Zarathustra as a "ritual hero of Iranian culture," leading to the construction of a "full-bodied prophet" in Mani after the model of the gospels; 6) the adoption of Iranian heroic legends; 7) the divergent creation of an ethos specific to Manichaeism and, respectively, Zoroastrianism; and finally, 8) the use of eschatology as a platform of circulating end of the world notion between JudeoChristian traditions and Zoroastrianism/Manichaeism. The contribution this article makes to scholarship resides in a radical rethinking of the formation of Zoroastrianism, as a reaction to cultural developments in Manichaeism. BeDuhn states clearly that Zoroastrianism "came into existence as a nativist and traditionalist reaction to conditions of religious options and innovations that existed in the third century. Like Judaism developing against the challenge of Christianity, or Hinduism developing against the challenge of Buddhism, such a nativist and traditionalist reaction has the quality of reinforcing the traditional interchangeability of religious and ethnic identity" (49).

In “ 'Religion' in Late Antique Zoroastrianism and Manichaeism: Developing a Term in Counterpoint," Kianoosh Rezania (2020) engages with Jason BeDuhn's earlier major text on the formation of "religion" as a "disembedded system of cultic practices" suitable for dissemination across various cultures and languages (BeDuhn 2015, 270). Rezania's examination of the occurrences of the "Middle Persian lexeme $d \bar{e} n / \delta \bar{e} n$ in Manichaean and Zoroastrian corpora" (6) yields a rich semantic palette of these terms. His analysis points to the meaning of daēna- as "vision" in Old Avestan texts and indicates that its connection, as "vision-soul," to the mytheme of the "moment of consultation (həm.̄paršti;-Y.33.6) with Ahura Mazdā" intersected with the later designations of the lexeme daēna- in Young Avestan texts, as ritual guide, to establish "semantical relationships" between the "psychopomp" functions of daēnāand "religion." Rezania's metaphorical mapping superimposes the concatenation of "vision," "soul," and "assistance along the way," together with eschatological evaluations developed in the Young Avestan texts, and ritual and eschatological aspects of concerns with the postmortem fate of the soul. "The semantic field of daenna- intersects with the following fields: ritual, guiding in ritual and postmortem life (psychopomp), ritual or traditional text, tradition, law, conduct of life, as well as community" (22) Rezania contends, and uncovers the quiescent ground for a full development of the term "religion" in the third century CE, because of exchanges between Mani's organization and Kerdīr's version of Zoroastrianism. The novelty of Rezania's contribution resides in the investigation of the occurrences of den in Manichaean texts written in Middle Persian, Parthian, and Sogdian, in the plural and singular, at the syntactic level, and then in the extension of this exploration to its semantic and pragmatic aspects, opening the door for the evaluation of similarity in the study of religious contacts. Says Rezania: "When we encounter a Manichaean comparison between 'religions,' we can assume that the Manichaeans used a generic concept of RELIGION" (63). With this approach, Rezania's linguistic assessment supports and confirms BeDuhn's 2015 hypothesis, and it establishes fertile grounds for further research in that it determines that both Mani and Kerdīr, the Zoroastrian state priest and his contemporary, wrestled with and promoted 
divergent hierarchical formulations of the binomial correlation between "one's own religion" and "other people's religions." As a result, Rezania notices, Mani set in place a hierarchy of religions open to religious plurality, which might have resulted in, or even be the result of, ulterior Manichaean multilingualism, while Kerdīr's vision of Zoroaster, as reflected in his inscription, depicts Zoroastrianism as shaping religious plurality according to a conservative dualist outlook. "Manichaeism accepted the presence of other entities in the religious field as 'religions,' thus acknowledging the plurality of religions in third-century Iran. Third-century Zoroastrianism discredited other entities and presented itself alone as religion, a position that could be accounted for, to some degree, up to the end of the first millennium C.E." (88).

Götz König implements a similar vision of cultural allotment between later antique Zoroastrianism and Manichaeism. In "From Manichaeism to Zoroastrianism. On the History of the Teaching of the 'Two Principles'" (2020), König places Manichaean dualism between earlier formulations of it in the Younger Avesta and later reactions to it by Zoroastrian theologians. König establishes three principles that guide his analysis of the formation of the Iranian religions: "1) religious competition and demarcation; 2) theoretical considerations within one religion; 3) the adoption of philosophical models" (4). In his distilled assessment of the ways Zoroastrian theologians associated "evil" to "finitude" and had both articulated by the ontological weight of "principle," König summons the early Greek philosophical discussion of the "principle" following Anaximander and establishes its connection to the Iranian cosmological model. Iranian cultures already possessed a term "principle" and the concept "of [the teaching of] the two principles" after 500 BCE. Given that Mani's central teaching was the one about the two principles, and that he "had access to the (still unwritten?) Avesta probably in its Pahlavi translation(s)" (12), König suggests regarding it as "the fulfilment of metaphoricalconceptual tendencies that can be found only in the Avesta" (14). Mani reworked, König shows, two major positions in the Younger Avesta, namely that light combines with the good and the lack of light, hence darkness, becomes evil, especially in its material aspects. Zoroastrian responses worked to undo the Manichaean position and to find "ways not to radically separate light from matter" (19). Its representatives distanced themselves from the rejection of matter to avoid economic issues and, against Manichaeism, "to formulate a dualism in which light, darkness, and matter could be set as an alternative and convincing constellation" (20). If Materia cannot be identified with darkness and evil because this would grant it an "indefinite" character, König infers from Ādurbād's argument in Dk 3.199.7, against Mani's teaching in $D k$ 3.200, then this leads to the exclusion of matter from the discussion of the eternal two principles. It also causes the scholar to question the relation between the two and to further inspect it: should light be considered as a physical phenomenon or as a metaphysical concept (26)? The development of the notion of divinity in Bundahišn presents structural similarities with Aristotelian philosophy, König argues. Moreover, the dual understanding of light as metaphysical notion and as charged with material features might have been influenced by the "adoption" of Aristotelian and Neoplatonic conceptions of finitude, infinite, and the matter: "Neoplatonism was attractive to the Zoroastrian authors because it offered a solution for the conflicts between a) philosophy and theology, and b) god and the world, both of which became prominent in late Antiquity. The emanation model enabled the construction of a coherent world. 'Light' is seen as a metaphor of this coherence, but also as a kind of 'connector of the transcendent/infinite with the immanent/finite'" (35). If Mani and his followers drew on Young Avesta to establish the distinction between Evil/Matter and Good/Light, König argues that Zoroastrian religious writers countered it by adopting various models from late antique 
philosophy of Greek expression to relate matter to the two principles "through light which itself exists as fire and endless lights, as material and immaterial light” (41).

As a preliminary conclusion, one notices that a common thread emerges from the above reviewed contributions to indicate that all contributors concentrated on the cultural, linguistic, philosophical, social, and political interstices of "formative religions." Both BeDuhn and König uncover the epistemological motivations for the shapes the exchanges between Manichaeism and Zoroastrianism took in late antique Iran. BeDuhn recognizes "permutations" with which Mani, Kerdirr, and their respective followers operated in their adoptions of Iranian cultural traditions. For BeDuhn, Mani establishes the major religious figures as precursors who shared wisdom, or "permutation of the same truth" (2020, 7). If traditions become movable parts in processes of cultural adoption, then to the variety of religious practices and beliefs BeDuhn oppose "religious pluralism" that is the awareness and practice of religious competition. The contribution his article makes to scholarship lies in a radical rethinking of the formation of Zoroastrianism, and less of Manichaeism.

Similarly, in exploring the philosophical relevance of "time" in Zoroastrianism and its connections to Aristotelian and Platonical schools, König identifies and traces "fulfilment of metaphorical-conceptual tendencies" in the theological and philosophical systems shared between Manichaeism and Zoroastrianism, with the adoption of Hellenized forms of classification and thought. Likewise, Rezania's contribution highlights the transitory aspects of the formative religious processes when it uncovers a moment of supposed linguistic errancy in Mani's speech in M 5794, in which "a plural adjective qualifies a singular noun": "Mani's difficulty to formulate the word dēn in the plural in third-century Iran more than its plural use in one case. Nevertheless, the passage lets us conclude that, in his theory of religion, Mani acknowledged not only religious plurality but also a hierarchy of religions."

It is precisely the same sort of closed reading of paintings, texts, and contexts that leads Gulàcsi to promote a healthy destabilization off the logocentric tendencies of scholarship on education in late antique Judaism and Manichaeism by isolating four main types of characteristics of the shared visual and religious cultures between the Manichaeans and the Jews of Mesopotamia: "(1) the defining importance of an oral religious culture surrounding them, (2) evidence about live discussions of religious teaching preserved in them, (3) the need for a skilled teacher to sermonize with them, and that (4) they most likely played a leading role in image-based sermons" (Gulácsi 2020). Finally, having explored the theological, social, and political consequences of the correlation between structured millenarian "time" and evil in Zoroastrianism and early Christianity, Panaino includes an anthropological coda and draws the chart of a Mazdean cosmology galvanized by Ahreman's "mentally suffering drive": Evil is not only a matter of deprivation but, for Panaino's reconstruction of Zoroastrian eschatology, a matter of mental suffering, whose very own impermanence opens the gates to personal restoration: "The Zoroastrian final optimistic solution of the definitive mercy of God toward everybody, a solution that also includes the sinners of hell, implicitly assumes that the damned are not completely responsible for their faults" (Panaino 2020, 26-27).

We have mentioned above the theoretical underpinnings of two more conferences on the topic of "formative encounters," which took place at Ruhr-Universität Bochum in 2018 and 2019 and were organized by Eduard Iricinschi and Kianoosh Rezania. The articles we gathered in this first issue of Entangled Religions, dedicated to formative religious exchanges in late Antiquity, were developed in dialogical engagement, reflecting the academic and oral environment in which they were initially presented. This collection represents the first step in 
an academic enterprise which will continue in 2021 with the publication of two more Entangled Religions special issues, dedicated to the exploration of formative cultural and religious entwinements between Zoroastrianism, Manichaeism, and Buddhism, following the presentations of the 2018 KHK workshop, and respectively, Zoroastrianism, Manichaeism, and Islam, reflecting the work of the 2019 KHK meeting.

\section{References}

BeDuhn, Jason. 2015. "Mani and the Crystallization of the Concept of 'Religion' in Third Century Iran." In Mani at the Court of the Persian Kings: Studies on the Chester Beatty Kephalaia, edited by Iain Gardner, Jason BeDuhn, and Paul Dilley, 247-75. Nag Hammadi and Manichaean Studies 87. Leiden: Brill.

- 2020. "The Co-Formation of the Manichaean and Zoroastrian Religions in ThirdCentury Iran." Entangled Religions 11 (2). https://doi.org/10.46586/er.11.2020.8414.

Gulácsi, Zsuzsanna. 2020. "Teaching with Images Among the Jews and Manichaeans of Late Antique Mesopotamia.” Entangled Religions 11 (2). https://doi.org/10.46586/er.11.202 0.8440 .

Hodgson, Marshall G. S. 1974. The Venture of Islam: Conscience and History in a World Civilization. 3 vols. Chicago, IL: Chicago University Press.

König, Götz. 2020. "From Manichaeism to Zoroastrianism: On the History of the Teaching of the 'Two Principles'." Entangled Religions 11 (2). https://doi.org/10.46586/er.11.2020. 8573.

Krech, Volkhard. 2012a. "Dynamics in the History of Religions-Preliminary Considerations on Aspects of a Research Programme." In Dynamics in the History of Religions Between Asia and Europe: Encounters, Notions, and Comparative Perspectives, edited by Marion Steinicke and Volkhard Krech, 15-70. Dynamics in the History of Religions Between Asia and Europe 1. Leiden: Brill. https://doi.org/10.1163/9789004225350.

— 2012b. "Religious Contacts in Past and Present Times: Aspects of a Research Programme." Religion 42 (2): 191-213. https://doi.org/10.1080/0048721X.2012.642572.

Panaino, Antonio. 2020. "Mazdeans and Christians Facing the End of the World: Circulations and Exchanges of Concepts." Entangled Religions 11 (2). https://doi.org/10.46586/er.11 .2020.8441.

Reeves, John C. 2011. Prolegomena to a History of Islamic Manichaeism. Sheffield: Equinox.

Rezania, Kianoosh. 2020. "'Religion' in Late Antique Zoroastrianism and Manichaeism: Developing a Term in Counterpoint.” Entangled Religions 11 (2): en. https://doi.org/10.4 6586/er.11.2020.8556.

Taves, Ann. 2009. Religious Experience Reconsidered: A Building-Block Approach to the Study of Religion and Other Special Things. Princeton, NJ: Princeton University Press. 